\title{
KENNETH MICHAEL SYLVESTER \\ Immigrant Parents, Ethnic Children, and Family Formation in the Early Prairie West
}

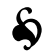

During the first thirty years that Canada supervised the settlement and development of its western interior, ambitions for population growth were routinely disappointed. Only a shrinking supply of arable land in the American West definitively shifted the sights of land-hungry immigrants to the colder northern plains. But when development did arrive at the end of the nineteenth century, renewed economic growth and transatlantic migration both assured a larger role for the foreign born in settling the Canadian plains, a role much bigger, as it turned out, than in the American west. ${ }^{\mathrm{I}}$ Still, many contemporaries worried that excessive pluralism hinted at further delay. Peasant farmers from continental Europe, at various stages of casting off the legacies of feudal exploitation, tended to cluster together in the western landscape. Initially, when Canada's early social scientists sought to explain this concentration, they viewed it as part of a distinct pattern. In the I930s a team of McGill sociologists and economists theorized that organized forms of 'group settlement' best explained the ongoing ethnic divergence from individualistic and anglicizing paths of development. ${ }^{2}$

I Royden Loewen illustrates some of the magnitudes in his Ethnic Farm Culture in Western Canada (Ottawa: Canadian Historical Association 2002), Canada's Ethnic Groups Series, Booklet No. 29. By I9II the proportion of the rural population in the three Prairie provinces which was not English, French, or Aboriginal was already substantial, but reached nearly half of the region's rural population by I93 ( $43.5 \%$ in Manitoba, 51.8\% in Saskatchewan, and 45.3\% in Alberta). Measured differently, according to birthplace of persons born outside Canada, the much larger presence of the foreign born in Canada was evident earlier as well. In I900 the US census showed that 7.I per cent of the rural population in the American Midwest and I2.5 per cent in the American West were foreign born. In western Canada, by contrast, the foreign born already formed 24.6 per cent of the rural population in I9oI, just as immigration to western Canada began to accelerate. See Kenneth Michael Sylvester, 'All Things Being Equal: Land Ownership and Ethnicity in Rural Canada, I90I,' Histoire sociale/Social History 34, 67 (200I): 35-60, table I.

2 On the provenance of the Frontiers of Settlement project and the genesis of social sciences in Canada more generally, see Marlene Shore, The Science of Social

The Canadian Historical Review 84, 4, December 2003

(C) University of Toronto Press Incorporated
\end{abstract}




\section{The Canadian Historical Review}

In one way or another, the history of peopling the Canadian plains has been influenced by this compartmentalized view of ethnicity ever since. 3 While social history has insisted that ethnic boundaries were more permeable and has drawn attention to conflict and inequality within ethnic groups, change is still largely conceived in terms of cultural preservation rather than adaptation. ${ }^{4}$ Wrestling more directly with continuity and discontinuity, the recent immigration literature has widened our lenses to transnational spaces. ${ }^{5}$ In these accounts, we are told of the

Redemption: McGill, the Chicago School, and the Origins of Social Research in Canada (Toronto: University of Toronto Press i987). On the original group settlement concept, see Carl A. Dawson, Group Settlement: Ethnic Communities in Western Canada (Toronto: Macmillan I936).

3 Raymond Breton first put forward the idea of institutional completeness in an article published in 1964, 'Institutional Completeness of Ethnic Communities and the Personal Relations of Immigrants,' American Journal of Sociology 70 (I964): I92-205, and he reflected more recently on the concept in 'Diversity and Homogenity: The Ambivalence of Canadians,' in Fred Stambrook, ed., A Sharing of Diversities: Proceedings of the Jewish Mennonite Ukrainian Conference 'Building Bridges' (Regina: Canadian Plains Research Center I999). Historical geographers still find the concept very useful because of the physical signature of cultural groups in agricultural landscapes. See, among others, James Darlington, 'The Ukrainian Impress on the Canadian West,' in Lubomyr Luciuk and Stella Hryniuk, Canada's Ukrainians: Negotiating an Identity (Toronto: University of Toronto Press with Ukrainian Canadian Centennial Committee I990), 53-80; and John C. Lehr, 'Crown, Corporation and Church: The Role of Institutions in the Stability of Pioneer Settlements in the Canadian West, I870-I9I4,' Journal of Historical Geography 2I (I995): 4I3-29.

4 For discussions of permeable social boundaries, see Gerald Friesen, The Canadian Prairies: A History (Toronto: University of Toronto Press I984); John Herd Thompson, Forging the Prairie West: The Illustrated History of Canada (Toronto: Oxford University Press I998); and especially Dirk Hoerder, Creating Societies: Immigrant Lives in Canada (Montreal and Kingston: McGill-Queen's University Press I999). Kathleen Neils Conzen makes the argument for locally hegemonic cultures in her 'Making Their Own America: Assimilation Theory and the German Peasant Pioneer,' German Historical Institute Annual Lecture Series 3 (1990), and 'Mainstreams and Side Channels: The Localization of Immigrant Cultures,' Journal of American Ethnic History II, I (I99I): 5-20. The making of local creoles and the importance of inter-ethnic relations are the unifying themes of distinctly different but conceptually important works: Donna Gabbaccia, We Are What We Eat: Ethnic Food and the Making of Americans (Cambridge: Harvard University Press I998); and Theodore Binnema, Common and Contested Ground: A Human and Environmental History of the Northwestern Plains (Norman: University of Oklahoma Press 200I).

5 The best expositions of civic engagement in the Canadian literature are Royden Loewen, Family, Church and Market A Mennonite Community in the Old and New Worlds, 1850-I930 (Urbana: University of Illinois Press 1993); and Frances Swyripa, 
Parents, Children, and Family Formation in the Early Prairie West 587

socially embedded nature of ethnic communities, of the-authority wielded by parents, and the expectations placed on children. Narratives reconstructed from surviving diaries tell of long days spent working for parents - seeding, weeding, harvesting, tending to livestock, chopping wood, weaving, sewing, cooking - and also for neighbours and other employers to earn wages while farms remained small and crops sparse. They tell of visits to family and neighbours, church meetings, and social events, of kinship-centred patterns of migration, and of residential persistence and civic engagement over time. But often the sinews of household governance, the basic processes of how generations succeeded one another, are left out of view. The oversight has confined historical inquiry, in one way or another, to simply restating an assumption that foreign and native-born cultures were worlds apart.

The idea that ethnic family governance created communities whose members became more socially connected than their Anglo-American or Anglo-Canadian neighbours retains a wide currency. ${ }^{6}$ In historical writing, the concept has probably received its fullest expression in the work of Jon Gjerde, who, in studying Norwegian settlement in the American Midwest has argued that greater expectations rested on foreignborn youth to stay and to labour. More than merely noting this difference at the time of arrival, Gjerde elevates it to a lasting divide between succession-oriented European and individualistic American modes of family reproduction. In an account that integrates sophisticated demographic analysis with evocative use of literary evidence, Gjerde makes the case that immigrant youth were consistently more selfless after arriving in North America than were native-born Americans.7 Indeed, Yankee

Wedded to the Cause: Ukrainian-Canadian Women and Ethnic Identity, 1891-1991 (Toronto: University of Toronto Press I993). Loewen has since published a remarkable collection of the farm diaries of Mennonite immigrants he used in his earlier work, including rare diaries of farm children, in From the Inside Out: The Rural Worlds of Mennonite Diarists, 1863 to 1929 (Winnipeg: University of Manitoba Press 1999).

6 For the argument about the persistence of civic engagement and social capital, over time, see Sonya Salamon, Prairie Patrimony: Family, Farming and Community in the Midwest (Chapel Hill: University of North Carolina Press I992); Myron P. Gutmann and Sara M. Pullum, 'From Local to National Political Cultures: Social Capital and Civic Organization in the Great Plains,' Journal of Interdisciplinary History 39, 4 (I999) 725-62; and Glen H. Elder Jr and Rand D. Conger, Children of the Land: Adversity and Success in Rural America (Chicago: University of Chicago Press 2000).

7 The dichotomy idea is developed in Gjerde, The Minds of the West: Ethnocultural Evolution in the Rural Middle West, 1830-I9I7 (Chapel Hill: University of North Carolina Press I997). A co-authored piece with Anne McCants, 'Individual Life Chances, I850-I9I0: A Norwegian-American Example,' Journal of Interdisciplinary 


\section{The Canadian Historical Review}

farmers in the Midwest complained, borrowing from the language of the grievance used by the labour movement, that immigrant farmers exerted levels of authority over their children that constituted a form of 'unfair labor.' ${ }^{\text {' }}$

To date, the consistency of the dichotomy has not been widely tested. Until the I990s, venturing outside a limited geography was prohibitive for most historical research. The most exhaustive research of household dynamics tended to be local, intergenerational, and even transnational, reconstructing the experiences of whole villages, parishes, or municipalities in their movement from old to new worlds. ${ }^{9}$ But when our inquiry is not limited to a single ethnic group, the kind of survey instrument embodied by Canada's historical censuses is the most representative historical window on wider geographic experiences and contexts. Not only was the same questionnaire put to the entire population but the creation of widely available public use samples has allowed researchers to question the raw responses in new ways, to deconstruct the official tabulations, and retabulate them in ways that are more relevant to current problematiques.

This article makes extensive use of a recent public use sample of the I90I census of Canada, one that promises to be the first of many from the early twentieth century. ${ }^{10}$ For a region as large as the Prairie West, no

History 33, 3 (1999): 377-405, looks at the propensity for young immigrants to stay at home.

8 Gjerde, Minds of the West, I98-9.

9 Jon Gjerde, From Peasants to Farmers: The Migration from Balestrand, Norway to the Upper Middle West (Cambridge: Cambridge University Press 1985); Robert C.

Ostergren, A Community Transplanted: The Trans-Atlantic Experience of a Swedish Immigrant Settlement in the Upper Middle West, 1835-1915 (Madison: University of Wisconsin Press 1988) and Loewen, Family, Church and Market.

Io The sample was created by the Canadian Families Project at the University of Victoria, with funding from the Social Sciences and Humanities Research Council. It is a randomized 5 per cent sample of dwellings, as those dwellings appear in the population schedule of the manuscript returns of the I90I census which were already available to the public on 129 microfilm reels. There are 50,943 dwellings and 265,287 persons in the sample from a national population of 5,37I,3I5. In this article I have used a subset of the data for the Canadian Prairies by selecting the 397I dwellings and I9,590 persons in the sample enumerated in Manitoba and the North-West Territory. For further information about the sample, see Eric W. Sager, 'The Canadian Families Project,' The History of the Family: An International Quarterly 3 (I998): II7-23. Funding for the collection of further public use samples was announced in January 2002. The project, known as the Canadian Century Research Infrastructure, has headquarters at the University of Ottawa, with partners at Memorial University of Newfoundland, Université Laval, Université de Québec à Trois-Rivières, York 
Parents, Children, and Family Formation in the Early Prairie West 589

other source provides as uniform a survey of the population. Other demographic sources exist, including parish registers or vital statistics, but they do not provide the same geographical coverage or detail on individuals and households. Viewed at the micro-level, the census information suggests that, even at the early stages of agricultural settlement, the gap between foreign- and native-born households was not as large as the one generally theorized. It is clear that immigrant and nativeborn families shared many strategies at the level of individuals and households. Where they differed most, it turns out, was in the urgency the newcomers attached to becoming landowners and farmers. Ironically, this motivation meant that some ethnic farm youth were quicker to leave the parental nest and that multigenerational homes were rarer than expected among recent immigrants.

In an era when most children lived in the countryside, the youth of new farm areas amplified the concerns of many social reformers that too many immigrant children lived beyond the reach of legislative intervention. ${ }^{\text {II }}$ Not only were immigrant communities younger, because elderly relatives were often left behind, but immigrant parents tended to have larger families during the first generation in North America. Farm parents, as they have ever since, always managed to deflect criticism of larger families and a regime of daily chores and seasonally heavy duties that was expected of children by arguing that work on the family farm did not detract from education or the formation of adult character. But in the context of dramatic increases in transatlantic migration, many contemporary observers worried that that immigrant families were too different. With their traditional dress and meagre possessions, it was

University, University of Toronto, and University of Victoria. For further information, contact the Institute for Canadian Studies at the University of Ottawa or visit the institute's Website: www.uottawa.ca/academic/arts/cdn/front.htm.

II Viviana A. Zelizer, Pricing the Priceless Child: The Changing Social Value of Children (New York: Basic Books I985), 77. For recent work specifically on farm children, see Pamela Riney-Kehrberg, 'The Limits of Policy: Rural Children and Work in the United States and New Zealand, I870-1920,' History of the Family 6, I (2001): 5I-67; and Linda Peavy and Ursula Smith, Frontier Children (Norman: University of Oklahoma Press I999). For the best examination of children in the industrial family economy in Canada, see Bettina Bradbury, Working Families: Age, Gender and Daily Survival in Industrializing Montreal (Toronto: McClelland \& Stewart I993). For the experience of children in rural life, see especially Neil Sutherland, Growing Up: Childhood in English Canada from the Great War to the Age of Television (Toronto: University of Toronto Press I997), chap. 7; and Robert McIntosh, Boys in the Pits: Child Labour in Coal Mines (Montreal and Kingston: McGill-Queen's University Press 2000). 


\section{The Canadian Historical Review}

thought that these 'pre-modern' newcomers did not share enough of mainstream society's changing views of childhood.

Urban social reformers, in particular, could not hide their incomprehension of peasant practices, blurred gender roles, and heavy demands on children. While serving as the superintendent of the All People's Mission in Winnipeg, J.S. Woodsworth publicly expressed his concerns, and those of many Anglo reformers, about the desirability of certain 'new' immigrants. In a book published in I909, Strangers within Our Gates, this head of western Canada's largest immigrant reception centre singled out Galicians and Bukovynians for their high levels of illiteracy and tendencies towards criminal behaviour. In a later study, authored while serving as head of the Manitoba government's short-lived Bureau for Social Research, Woodsworth noted that nearly two-thirds of the Ukrainian women 'surveyed' said that they worked in the fields beside their husbands and that nearly all their children were given farmyard chores and a high proportion worked in the fields as well. ${ }^{\mathrm{I2}}$ His report expressed worry about these practices and the effects of such strenuous activity on women's health, child care, and domestic duties. In retrospect, the details of the report reveal far more about urban middle-class ideas of domesticity than the realities of rural life. ${ }^{\mathrm{I}}$

While the prescriptive tone of these early observations has drawn comment, the urban teleology, ironically, has not. Reformers implied that social and economic progress demanded a reduction in child labour or at least its displacement by technology, but metropolitan timetables could not be said to regulate life in the countryside closely, particularly in

I2 James S. Woodsworth, dir., 'Ukrainian Rural Communities,' report of investigation by the Bureau of Social Research, Winnipeg I9I7, mimeograph, cited in Swyripa, Wedded to the Cause, 29-3I

I3 Many studies have questioned the inflexibility of the separation of spheres detailed in Majorie Griffin Cohen's classic account, Women's Work, Markets, and Economic Development in Nineteenth-Century Ontario (Toronto: University of Toronto Press I988). See, among others, Sarah Brooks Sundberg, 'A Female Frontier: Manitoba Farm Women in I922,' Prairie Forum I6, 2 (I991): I85-204; Royden Loewen, “'The Children, the Cows, My Dear Man, My Sister": The Transplanted Lives of Mennonite Farm Women, I874-I900,' Canadian Historical Review 73, 3 (1992): 344-73; Terry Crowley, 'Experience and Representation: Southern Ontario Farm Women and Agricultural Change, I870-I9I4,' Agricultural History 73, 2 (I999): 238-5I; and, on the American experience, Jane Marie Pederson, Between Memory and Reality Family and Community in Rural Wisconsin, 1870-1970 (Madison: University of Wisconsin Press I992); Katherine Jellison, Entitled to Power: Farm Women and Technology, 1913-1963 (Chapel Hill: University of North Carolina Press 1993); and Mary Neth, Preserving the Family Farm: Women, Community and the Foundations of Agribusiness in the Midwest, 1900-1940 (Baltimore: Johns Hopkins University Press I995). 
terms of the demography of farm families. ${ }^{\mathrm{I}}$ The arrival of so many newcomers certainly complicated the picture, conflating persistently higher rural fertility with ethnicity, but fertility decline in the countryside continued to lag behind urban transitions well into the twentieth century. ${ }^{\text {I5 }}$ Across North America the contrast between the native- and foreign-born populations was more dramatic in areas where fertility began to decline early, as in New England, but in regions where agriculture remained dominant, demographic conditions were not very different from similar settings in Europe.$^{16}$ Fears that higher rates of immigrant fertility would overwhelm Anglo-Saxon stock were based on what turned out to be short-lived differences. Often within a generation, a handful of studies that have looked at the issue suggest, the children of immigrants tended to reduce family sizes to levels of other native-born parents, both in the city and in the countryside. ${ }^{17}$

I4 The many and varied transitions to capitalism in Europe and America have not preoccupied writing about rural life in Canada. But it is now commonplace in the literature on agricultural change to focus on local innovation and locally specific paths of development. For a review of the early modern European experience, see Robert S. Duplessis, Transitions to Capitalism in Early Modern Europe (Cambridge: Cambridge University Press I996); and for the American experience, Richard Lyman Bushman, 'Markets and Composite Farms in Early America,' William and Mary Quarterly 55, 3 (I998): 35I-74. For the influence of the metropolitan thesis on Canadian writing, see Robert Irwin, 'Breaking the Shackles of the Metropolitan Thesis: Prairie History, the Environment and Layered Identities,' Journal of Canadian Studies 32 (I997): 98-II8; and Ruth Sandwell, 'Rural Reconstruction: Towards a Reassessment of Nineteenth Century Canadian Historiography,' Histoire sociale/Social History 27, 53 (I994): I-32. On the diffusion of technology in agriculture and the persistence of family farming, see Nancy Johnson and Vernon Ruttan, 'Why Are Farms So Small?' World Development 22, 5 (I994): 69I-706; Vernon W. Ruttan, Technology, Growth and Development: An Induced Innovation Perspective (New York: Oxford University Press 200I); or Mil Penner, Section 27: A Century on a Family Farm (Lawrence: University of Kansas Press 2002).

I5 Elder and Conger, Children of the Land (2000); Myron P. Gutmann, Sara PullumPiñón, and Thomas W. Pullum, 'Three Eras of Young Adult Home Leaving in Twentieth-Century America,' Journal of Social History 35, 3 (2002): 533-76.

I6 John E. Knodel, Demographic Behavior in the Past: A Study of Fourteen German Village Populations in the Eighteenth and Nineteenth Centuries (Cambridge: Cambridge University Press I988); Ansley J. Coale, 'The Decline of Fertility in Europe since the Eighteenth Century as a Chapter in Demographic History,' in Ansley Coale and Susan C. Watkins, eds., The Decline of Fertility in Europe (Princeton: Princeton University Press I986), I-30.

I7 For a discussion of the convergence among German immigrants in Texas and the impact of religion on the slower decline of fertility among German Catholics see Miriam King and Steven Ruggles, 'American Immigration, Fertility and Race 


\section{The Canadian Historical Review}

Immigration did, however, have a discernable impact on regional population patterns. In 1890 in the northern United States, for instance, the ratio of youth (those aged nineteen and under) per roo adults (aged twenty and older) was higher the further west one looked, ranging from a low of fifty-eight in New England to a high of ninety-two in the most recently settled northern states. ${ }^{18}$ Yet the size of the farm economy was still decisive. The youngest region in the United States, where the ratio of the young to the adult population never fell below Ioo before I890, remained the American South. ${ }^{19}$ Irrespective of the time since colonization, the proportion of children in the population remained strongly related to the level of agricultural activity. Children were simply more numerous wherever they did not yet represent an economic penalty to their parents.

Canadian census figures illustrate similar trends in the Prairie West. Before we turn to them more directly, however, the measurement of ethnicity in Canada's censuses requires some explanation. Because of its bilingual foundations, the Canadian state has tracked ancestry in a different way than the United States. Canadian authorities, who were concerned about the strength of French Canada in the new political union, included questions in the country's first census in i87i about birthplace and 'origins.' Controversy ensued after early tabulations of the country's first census appeared to inflate French Canada's numbers. ${ }^{\circ \circ} \mathrm{In}$

Suicide at the Turn of the Century,' Journal of Interdisciplinary History 20, 3 (I990): 347-69; and Myron P. Gutmann and Kenneth H. Fleiss, 'The Determinants of Early Fertility Decline in Texas,' Demography 30, 3 (1993): 443-57.

I8 I am referring here to the states in the West North Central Division census division - namely, Iowa, Kansas, Minnesota, Missouri, Nebraska, North Dakota, and South Dakota. For discussion of the generally higher fertility in new farm areas in the United States, see Yasukichi Yasuba, Birth Rates of the White Population in the United States, 1800-1860: An Economic Study (Baltimore: Johns Hopkins University Press I962); Richard A. Easterlin, 'Population Change and Farm Settlement in the Northern United States,' Journal of Economic History 37 (1976): 45-75; and Jeremy Atack and Fred Bateman, To Their Own Soil: Agriculture in the Ante-bellum North (Ames: Iowa State University Press I987).

I9 See David I. Macleod, The Age of the Child: Children in America, 1890-1920 (New York: Twayne I998), table I, 4.

20 Bruce Curtis discusses the political purposes served by the 'origins' question in Canada's first national census in I87i. By tabulating ethnicity outside Quebec only on the basis of a father's origin and by marking up returns inside Quebec as 'Census French' if either parent was of French origin, Minister of Agriculture J.C. Taché could, according to Curtis, emphasize the importance of French and Catholic elements of the population. See The Politics of Population: State Formation, Statistics, 
subsequent censuses, the origins question was redefined to subdue some of the political storm. By I88I, opponents had failed to remove the national origins question from census returns, but in I89I succeeded in having it replaced with more explicit questions about birthplace and the birthplace of parents, with a direct question whether the person enumerated was French Canadian. By I9OI the elements of this identity matrix grew to include birthplace, nationality (by then, narrowed to indicate the country of citizenship), colour, language, religion, and 'race.'

Despite its Spencerian overtones, the reformulation of the 'origins' question as 'race' actually opened the door to a process of surprisingly open-ended self-identification. Enumerators were still instructed that they were not to record 'Canadian' or 'American' as legitimate responses to the race question, but the examples of European peoples in the instructions were vague enough that, once in people's homes, enumerators typically recorded whatever subnational identities people declared. Eastern Europeans, for instance, rarely responded to the 'race' question with pan-imperial identities. They might declare their citizenship as Austrian or Russian, but census respondents usually referred to their 'race' more specifically as Polish, Galician, Ruthenian, or Romanian.

The implications of the shift in census practice are important. Irrespective of how long each group was established in Canada, responses to the ancestry question serve as barometers of ethnic affiliation in past populations. Because residents of Canada were repeatedly encouraged to identify themselves as 'ethnic' persons and denied the chance to make themselves 'Canadian,' ethnic populations retain a self-identified, if evolving, meaning over time. This self-identified concept of ethnicity is very different from the one that can be constructed from the us census, which tracked the country of birth of each person and that of each person's mother and father. While the way the question was posed allows researchers to identify the children of immigrants, even when they no longer reside with parents, the window on ethnic experience lasts only two generations and does not permit the identification of subnational ethnic origins overseas.

In the Canadian census, because the children of immigrants cannot be identified unless they resided with their parents, one must think of the proportion of foreign born within each self-identified group in order to identify recent immigration experiences. By the time of the I90I census, the 'new' immigration from continental Europe had not yet peaked.

and the Census of Canada, 1840-1875 (Toronto: University of Toronto Press 200I), esp. chap. 8, 'The Pur Sang Census.' 


\section{The Canadian Historical Review}

To fashion groupings for the current analysis, broad geographical classifications were made, both for simplicity and to address longstanding debates in family history. ${ }^{2 \mathrm{I}}$ Readers must bear in mind that these classifications were based on self-identified ancestry and not birthplace. A finer parsing of identities is still possible when using the data, but detailed deconstruction of identities took a back seat here to examining differences among groups that were either largely foreign or native born.

A classification of ethnic groups along these lines demonstrates that international migration and agricultural expansion were having a dramatic effect on early population trends in Canada's Prairie West, as they had during Euroamerican settlement of the American plains. The sample Canadian returns are tabulated in table $\mathrm{I}$, to compare them with age statistics discussed above from the us census. The relative youth of predominantly foreign- or native-born groups are expressed in the upper panel as ratios, per hundred, of young to adult persons (the number nineteen and under divided by the number twenty and older). The lower panel presents the proportion of foreign born in each ethnic group and subdivides the proportions by age, to indicate how recent the immigration experience was in each subset of the population. Not surprisingly, the groups with the highest proportion of foreign born in their adult populations - the East Europeans, Scandinavians, and Germans, formed the youngest populations in the region. The only exception, among the mainly native-born groups, was the French.

Within each recent immigrant population, age distributions were affected by the relative absence of elderly relatives. Each was also characterized by spikes in the number of persons reaching mid-life or their midteens..$^{22}$ The numbers were elevated, presumably, by an adult generation

2I Grouped in the Eastern European category were all peoples with origins in the eastern provinces of the Austro-Hungarian Empire, the Balkans, the Baltics, and the western provinces of the Russian Empire. Immigrants who identified their 'racial' origin as Austrian were grouped into the German category. Mennonites from Russia were also grouped into the German category because they typically identified themselves as German in the race question. I checked to see if persons who spoke neither Russian nor German identified their 'race' as Russian or Austrian. Only a handful of cases exist where people declared to the enumerator that they spoke Galician and identified their 'racial' origin as Austrian. Asians, African Americans, Metis, and Aborginal peoples (typically those living off reserve) were grouped on the basis of their response to the 'race' question into a category for visible minorities. Group quarters, such as Aboriginal persons living on reserve or persons living in institutions, such as prisons or mental institutions, were excluded from the anlaysis. 22 This spike was especially visible in histograms (not shown) of the age distributions among East Europeans and Scandinavians. 
TABLE I

Ratio of Youth per Ioo Adults, and Proportions Foreign Born, on Farms and Off, by Ethnicity, Prairie West, I90I

\begin{tabular}{|c|c|c|c|c|c|c|c|c|c|}
\hline Prairie Youth & $\begin{array}{l}\text { Visible } \\
\text { Minority }\end{array}$ & $\begin{array}{c}\text { East } \\
\text { European }\end{array}$ & $\begin{array}{c}\text { North } \\
\text { European }\end{array}$ & German & French & Irish & Scots & English & Total \\
\hline \multicolumn{10}{|c|}{$\begin{array}{l}\text { Population age } 19 \text { and under } \\
\text { per } 100 \text { age } 20 \text { and older }\end{array}$} \\
\hline farm & 98.2 & 118.4 & 100.0 & 137.3 & 125.7 & 97.4 & 83.1 & 86.1 & 101.0 \\
\hline non-farm & 86.5 & 114.8 & 82.5 & 101.9 & 84.1 & 81.2 & 81.1 & 80.4 & 84.6 \\
\hline \multicolumn{10}{|c|}{$\begin{array}{l}\text { Proportion foreign born } \\
\text { farm }\end{array}$} \\
\hline 19 and under & 0.01 & 0.79 & 0.47 & 0.25 & 0.13 & 0.08 & 0.11 & 0.17 & 0.22 \\
\hline 20 and older & 0.04 & 0.99 & 0.95 & 0.79 & 0.27 & 0.19 & 0.34 & 0.49 & 0.47 \\
\hline \multicolumn{10}{|l|}{ non-farm } \\
\hline 19 and under & 0.01 & 0.67 & 0.30 & 0.32 & 0.05 & 0.06 & 0.06 & 0.14 & 0.14 \\
\hline 20 and older & 0.06 & 1.00 & 0.95 & 0.72 & 0.22 & 0.19 & 0.27 & 0.48 & 0.38 \\
\hline Number of cases & 1,417 & 1,176 & 875 & 2,565 & 1,233 & 3,221 & 3,741 & 4,794 & 19,022 \\
\hline
\end{tabular}

Source: PUMS, Census of Canada I90I 


\section{The Canadian Historical Review}

leading migration and a generation of maturing offspring, nearing succession. In long-established groups, where the proportion of native born was much higher, age distributions were more even, starting with a typically wide base at the youngest ages and thinning across the life cycle towards the ranks of the elderly. The French population was the only native-born group to mirror the age distribution of the immigrant groups, suggesting that westward migration was still very recent and focused on establishing farms. ${ }^{23}$ In fact, in statistical terms, if we treat each of the subpopulations as if they had the same demographic profiles, in terms of rural-urban residence, sex, and foreign birth, then individuals were more likely to be under the age of twenty if they were East European, Scandinavian, German, female, and living on a farm than if they were English, Scots, Irish, French, visible minority, male, or living off a farm. ${ }^{24}$

As the foregoing analysis shows, immigrant families were in a position to benefit more directly from the labour of children. But the question of how long these age differences continued to shape transplanted family regimes, organize the responsibilities of children, or plan transitions to adulthood is another matter. Without elderly generations present

23 When I compared youth to adult ratios in the sample data across Canada, Quebec had a slightly higher youth to adult ratio than the Prairies in I9OI, with most of its young not surprisingly concentrated in the farm population. The youth to adult ratio in the non-farm population was more in keeping with the rest of Canada. For recent analysis of the determinants of the transition in Quebec, see Daniel Gauvreau and Peter Gossage, 'Avoir moins d'enfants au tournant du XXe siècle: Une réalité meme au Québec,' Revue d'histoire de l'Amérique française 54, I (200I): 39ç65, and Peter Gossage, Families in Transition: Industry and Population in Nineteenth-Century SaintHyacinthe (Montreal and Kingston: McGill-Queen's University Press I999). I uncovered only small differences between French Catholics and English Protestants in a Prairie agricultural community. See Kenneth M. Sylvester, The Limits of Rural Capitalism: Family, Culture and Markets in Montcalm, Manitoba, 1870 to 1940 (Toronto: University of Toronto 200I), chap. 2.

24 This conclusion is based on a nominal regression, not shown in the text, estimating the odds that an individual in the subset of the national data set for the Prairies, containing age information for I9,02I persons, was either age nineteen or below or age twenty and above. Because the outcome (dependent variable) is binary, the results can be expressed in odds ratios, in relation to reference categories within each explanatory variable. The estimated odd ratios in a design that included ethnicity, a variable for rural-urban residence, sex, and foreign/native birth indicate that, compared with persons of English ancestry, East Europeans were 3.8 times more likely to be under the age of twenty, Scandinavians and Germans, two point one times, and that persons of French ancestry did not differ from the English population in a statistically significant sense. When religion was added to the design, the residual ethnic differences remained roughly the same, even though the categories for Catholic and Orthodox religions captured some of the variation. 
in the population, it is difficult to argue that what can be observed in I9OI were the beginnings of lasting patterns. Many historical observers have mused about the effects of thrusting so many different peoples into geometrically uniform land system, one that theoretically levelled social inequalities or at least stripped away layers of social hierarchy that were common in peasant society in Europe. The patterns of family formation that emerged in this institutional environment were arguably unburdened by the weight of the past practice or the tremendous variations underlying differences in European landscape, climate, and property relations. Often the differences in traditional contexts were too complex to reduce to elegant cultural or demographic theories.

Historical demographers have not failed in inventing useful shorthands. In I965 John Hajnal simplified historical differences in social reproduction by identifying a distinctive northwest European marriage pattern. West and north of a line stretching from Trieste to St Petersburg, twentieth-century census information showed that household formation was characterized by a high average age at marriage and a high percentage of women who never married. Marriage was typically delayed, Hajnal suggested, because couples expected to form independent households at the time of marriage. The northwest European system received further confirmation the following decade from Peter Laslett and others, who linked late marriage with property transmission and demonstrated that simple conjugal family households predated the industrial revolution. ${ }^{25}$ By contrast, family formation east of the line was thought to involve younger couples, nearly universal marriage, and extended family households. As a heuristic device, Hajnal's model has helped to provide a focus for historical demography but has not been able to measure up to the plurality of family forms found in detailed case studies of Eastern Europe, from the Balkans to the Baltic. ${ }^{26}$ And the work

25 Hajnal outlines the transition zone between East and West in 'European Marriage Patterns in Perspective,' in D.V. Glass and D.E.C. Everly, eds., Population in History: Essays in Historical Demography (London: Edward Arnold I965), IOI-43; Peter Laslett uses a more elaborate regional classification - northern, western, Mediterranean, and eastern - in 'Family and Household as Work Group and Kin Group: Areas of Traditional Europe Compared,' in R. Wall, J. Robin, and P. Laslett, eds., Family Forms in Historic Europe (Cambridge: Cambridge University Press I983), 513-63. See also E.A. Wrigley, R.S. Davies, J. Oeppen, and R.S. Schofield, English Population History from Family Reconstitution, 1580-1837 (Cambridge: Cambridge University Press I997); and Osamu Saito, 'Two Kinds of Stem Family System? Traditional Japan and Europe Compared,' Continuity and Change I3, I (I998): I67-86.

26 For recent work on Eastern Europe, see Charles Wetherell and Andrejs Plakans, 'Borders, Ethnicity, and Demographic Patterns in the Russian Baltic Provinces in the 


\section{The Canadian Historical Review}

with modern censuses has only complicated the received image of extended family households as fixtures of traditional society by documenting their persistence in the most advanced economies well into the twentieth century. ${ }^{27}$

Nevertheless, the core idea of the northwestern European system received a powerful assist in the North American environment, where relatively young ages at marriage in the countryside were generally a function of wider socio-economic conditions, such as the greater availability of land. Parents tended to use their landed wealth to assist children in establishing independent households locally or in migrating to the land frontier. ${ }^{28}$ The freedom allowed to intended couples to marry each other, independent of the control or interference of parents, became the signature of a simplified family model writ large in the North American landscape. ${ }^{29}$ This independence did not mean that parents failed to covet the labour of maturing children or intend for the youngest heirs to remain close at hand, to care for them in old age. Many of them, in fact, had to make use of the labour of strangers or extended kin when their children were young. Parents compensated in different ways during the life cycle, as Donald Parkerson has shown, by taking in kin or by hiring servants. In general, however they relied on family labour..$^{\circ}$

Late Nineteenth Century,' Continuity and Change I4, I (1999): 33-56; Karl Kaser, 'Power and Inheritance: Male Domination, Property, and Family in Eastern Europe, I500-I900,' History of the Family 7 (2002): 375-95; and Siegfried Gruber and Robert Pichler, 'Household Structures in Albania in the Early 2oth Century,' History of the Family 7 (2002): 35I-74.

27 Steven Ruggles, 'The Transformation of American Family Structure,' American Historical Review (1994): I03-28, table I. Ruggles shows that one-fifth of American families at the end of the nineteenth century contained extended kin, and that this proportion dropped significantly only after the Second World War.

28 For an overview of the family formation system in North America, see Gérard Bouchard, 'Family Reproduction in New Areas: Outline of a North American Model,' Canadian Historical Review 75 (1994): 475-510, or in a colonization area of nineteenth-century Quebec, his Quelques arpents d'Amérique: Population, économie, famille au Saguenay, 1838-1971 (Montréal: Les Éditions du Boréal 1996). For a recent survey of the colonial family formation system in New England, see Gloria L. Main, Peoples of a Spacious Land: Families and Cultures in Colonial New England (Cambridge: Harvard University Press 200I).

29 Daniel Scott Smith, 'The Meanings of Family and Household: Change and Continuity in the Mirror of the American Census,' Population and Development Review I8 (I992): 42I-56; and Daniel Scott Smith, 'The Curious History of Theorizing about the History of the Western Nuclear Family,' Social Science History I7, 3 (I993): 327-53

30 Donald Hugh Parkerson, The Agricultural Transition in New York State: Markets and Migration in Mid-Nineteenth-Century America (Ames: Iowa State University Press I995) 
Parents, Children, and Family Formation in the Early Prairie West 599

The key question, then, is how transplanted family systems interacted with this new environment. In what ways were parents trying to influence the transitions of rural youth to adulthood? Given the kind of population trends we have already seen, parents may certainly have tried to rely extensively on children. But we see from the household information that the adaptation process was more mixed. Immigrant youth were working outside the boundaries of family economies, and their parents were also hiring servants, although not to the same degree as among the native born. Two ways of measuring these phenomena can be fashioned from responses to questions on the population schedule: the proportion of young persons aged fifteen to twenty-four who were described as servants in the relationship to the head-of-household question in the census, $^{3 \mathrm{I}}$ and the proportion of persons aged fifteen to twenty-four reporting earnings are reported in table 2 . There is some overlap in the measures. By definition, youth who were identified as servants were living in households 'headed' by persons to whom they were not related, and youth who reported earnings could be living in their parents' home or they might be living in the homes of unrelated persons.

Here we see some indirect evidence of the broad difference theorized in the approach of native- and foreign-born parents. Recent immigration appears to be the most decisive factor in the trends seen in table 2, because it was the East European youth who came closest to the tradition of 'binding out' seen among English youth. Generally, the practice of youth being sent out to work for others and remitting earnings to parents seems to have declined in Canada as the nineteenth century progressed. ${ }^{32}$ Certainly, by historical standards in Europe, it was never a

3I Beginning in I88I, the relationship to the head-of-household question was asked of every enumerated person, who described his or her relationship to the nominal head of the household or the householder, typically the husband in most married-couple households. The examples furnished to enumerators in paragraph 48 of the I9OI instructions read: 'In column 6 the head of each family or household will be entered as such, and all others according the relationship - as wife, son, daughter, servant, boarder, lodger, partner, etc. The persons in an institution may be described as officer, inmate, prisoner, pupil, etc.' The contents of the relationship-to-the-head question changed over time, but it served as the principal means for understanding changes in the composition of households, based on census data. For a discussion of the challenges of integrating similar responses to the question over time, see Steven Ruggles, 'Family Interrelationships,' Historical Methods 28, I (I995): 52-8.

32 Gordon Darroch, 'Home and Away: Patterns of Residence, Schooling, and Work among Children and Never-Married Young Adults, Canada, I87I-I90I,' Journal of Family History 26, 2 (200I): 220-50. The census also included data about whether a person made 'extra' earnings from a secondary occupation, in most cases away from the usual place of residence. These extra earnings were added in the analysis to the annual earnings. 
TABLE 2

Proportions of Rural Youth Ages I5 to 24 Reporting Servant Status, and Earnings by Ethnicity and Sex, Prairie West, I90I

\begin{tabular}{|c|c|c|c|c|c|c|c|c|c|}
\hline Rural Youth & $\begin{array}{l}\text { Visible } \\
\text { Minority }\end{array}$ & $\begin{array}{c}\text { East } \\
\text { European }\end{array}$ & $\begin{array}{c}\text { North } \\
\text { European }\end{array}$ & German & French & Irish & Scots & English & Total \\
\hline \multicolumn{10}{|c|}{$\begin{array}{l}\text { Proportion reporting servant status } \\
\text { males }\end{array}$} \\
\hline $15-19$ & 0.03 & 0.16 & 0.05 & 0.11 & 0.03 & 0.10 & 0.06 & 0.22 & 0.11 \\
\hline $\begin{array}{r}20-24 \\
\text { females }\end{array}$ & 0.06 & 0.07 & 0.09 & 0.14 & 0.16 & 0.17 & 0.10 & 0.26 & 0.16 \\
\hline $15-19$ & 0.05 & 0.14 & 0.24 & 0.14 & 0.07 & 0.06 & 0.04 & 0.12 & 0.09 \\
\hline $20-24$ & 0.03 & 0.00 & 0.15 & 0.03 & 0.20 & 0.03 & 0.08 & 0.10 & 0.07 \\
\hline \multicolumn{10}{|c|}{$\begin{array}{l}\text { Proportion reporting earnings } \\
\text { males }\end{array}$} \\
\hline $15-19$ & 0.11 & 0.21 & 0.11 & 0.11 & 0.02 & 0.19 & 0.12 & 0.22 & 0.15 \\
\hline $\begin{array}{r}20-24 \\
\text { females }\end{array}$ & 0.17 & 0.22 & 0.26 & 0.24 & 0.24 & 0.34 & 0.28 & 0.37 & 0.30 \\
\hline $15-19$ & 0.00 & 0.11 & 0.20 & 0.09 & 0.08 & 0.05 & 0.09 & 0.07 & 0.08 \\
\hline $20-24$ & 0.05 & 0.00 & 0.15 & 0.05 & 0.06 & 0.09 & 0.16 & 0.09 & 0.09 \\
\hline \multicolumn{10}{|c|}{$\begin{array}{l}\text { Number of observations } \\
\text { males }\end{array}$} \\
\hline $15-19$ & 66 & 62 & 19 & 124 & 62 & 145 & 142 & 176 & 796 \\
\hline $\begin{array}{r}20-24 \\
\text { females }\end{array}$ & 65 & 27 & 23 & 102 & 50 & 155 & 148 & 227 & 797 \\
\hline $15-19$ & 49 & 47 & 25 & 106 & 60 & 110 & 128 & 163 & 688 \\
\hline $20-24$ & 58 & 26 & 20 & 87 & 35 & 93 & 107 & 142 & 568 \\
\hline
\end{tabular}

Source: PUMS, Census of Canada I90I 
Parents, Children, and Family Formation in the Early Prairie West 6oI

large feature of North American practice. Various estimates of servitude among the young in the early modern era suggest that between 30 and 40 per cent of European youth between the ages of fifteen and twentyfour might be out to service, and in a predominantly rural country like Ireland the proportion was equally high as late as I9II. ${ }^{33}$ In the Canadian plains, as we see, generally fewer than I5 per cent of rural youth reported themselves as servants during the same stage of life, in a region with the highest proportion of such service in the country. ${ }^{34}$

In general, immigrant youth were more likely to be servants in their teenage years, with the proportion of young men increasing into their early twenties, and the proportion of young women decreasing. East European, Scandinavian, and German females were particularly more likely to be servants than teens in the predominantly native-born groups, and the Germans and East Europeans were more likely to return to parental households or to marry when they reached their twenties. Young Scandinavian, French, and English women were the only ones to break this pattern, showing a higher tendency to remain servants into their early twenties and avoiding marriage. Patterns of participation in waged employment, however, do not break out in the same sort of divide between immigrant and native-born practice. Instead, the pattern is more gendered than ethnic, with a higher participation of young men in paid employment, signalling a transition to independence. For young women, participation dropped off dramatically in their mid-twenties for all but Scandinavian and Scots, indicating that paid employment was much more of a supplement to the income of parental households than a break with parents towards a more independent future.

Another distinct difference between predominantly native- and foreign-born groups was that immigrant farm parents were less likely to bring servants into their homes. Again, the difference was not dramatic, given the difficulties of adjustment, mastering language barriers, and learning the subtleties of local labour markets. If the proportions are expressed from the perspective of parental decision-making, it is evident that few households in each ethnic group were integrated into labour

33 For the modern period, see Timothy Guinnane, The Vanishing Irish: Households, Migration, and the Rural Economy in Ireland, 1850-1914 (Princeton: Princeton University Press 1997), and for the early modern period, Peter Laslett, 'The Characteristics of the Western Family Considered Over Time,' Journal of Family History 2, 2 (I977): 89-II6; Ann Kussmaul, Servants in Husbandry in Early Modern England (New York: Cambridge University Press I98I).

34 The proportion of rural youth out to service, for both sexes, was not higher than Io per cent in Ontario, 5 per cent in Quebec, and 4 per cent in the Maritimes. PUMS, Census of Canada I9o 


\section{The Canadian Historical Review}

markets as employers. The distribution of households in table 3 shows that, generally, one in five Irish, Scots, and English farm households had at least one or more servant. By comparison, only one in ten German and Scandinavian farm households had hired a servant in I9OI, and virtually no East European farm households. Immigrant groups were relying more on family labour than were more established ethnic groups. But with so few farm households employing servants in the region overall, it is difficult to elevate this divergence into a lasting dichotomy.

The longevity of the differences in behaviour between predominantly foreign- or native-born groups is particularly called into question, however, by the tendency for immigrant children to leave home almost as early as native-born youth. If the children of immigrants were more selfless, a survey as comprehensive as the census should show more signs of delay in the transition to independence. But relatively few indications of delay were found beyond the foreign-born generation of immigrant youth. This trend was especially evident when the sense of obligation to parents was tested in terms of whether youth were still residing with a parent. Using the responses to the relationship to the head-of-household question, children, adolescents, and young adults in the sample were categorized as living away from home if neither parent was present. And, rather than merely reporting the proportions away from home in each group, a multivariate approach was used to assess the hypothesis that immigrant youth were more likely, as individuals, to be at home than were native-born youth.

Statistically, the advantage of a multivariate design is the assessment it affords of individual life chances. Rather than merely reporting the proportions of young people away from home within each group, multivariate techniques allow us to evaluate the degree to which other characteristics - such as age, sex, marital status, earnings, or birthplace influenced the likelihood that an individual lived with at least one parent. Whereas proportions hint at the reasons for group differences, multivariate analysis allows us to evaluate how much of the difference between individuals was due to their membership in that ethnic group or to other characteristics.

The likelihood of living at home in the sample population was generated using nominal regressions, in four separate designs. Because the outcome was binary (living with a parent or not), the estimates presented in table 4 may be expressed as odds ratios. Two of the designs in table 4 segregate the odds of being at home by sex, pooling the populations of young men and women separately, a third uses all observations of individuals aged ten to twenty-nine in the Prairie data and adds sex as an explanatory variable, and a fourth adds an interaction term. A reference 
TABLE 3

Proportion of Farm Households with One or More Servants, by Ethnicity, Prairie West, I90I

\begin{tabular}{|c|c|c|c|c|c|c|c|c|c|}
\hline Farm Households & $\begin{array}{l}\text { Visible } \\
\text { Minority }\end{array}$ & $\begin{array}{c}\text { East } \\
\text { European }\end{array}$ & $\begin{array}{c}\text { North } \\
\text { European }\end{array}$ & German & French & Irish & Scots & English & Total \\
\hline $\begin{array}{l}\text { Percent with one or } \\
\text { servants }\end{array}$ & 4.4 & 1.1 & 10.7 & 10.5 & 13.7 & 19.4 & 21.0 & 18.0 & 15.5 \\
\hline Total number & 68 & 189 & 84 & 342 & 159 & 439 & 491 & 599 & 2,371 \\
\hline
\end{tabular}

Source: PUMS, Census of Canada I90I 


\section{The Canadian Historical Review}

TABLE 4

Odds of Being in Parent's Home by Age, Marital Status, Ethnicity, Sex, Nativity, Presence of Non-kin, Farm Population, Canadian Prairies, I90I

\begin{tabular}{|c|c|c|c|c|}
\hline Characteristics & Model I & Model 2 & $\begin{array}{l}\text { Model } 3 \\
\text { Women } \\
\text { \& Men }\end{array}$ & $\begin{array}{l}\text { Model } 4 \\
\text { Model } 3 \\
\text { \& Inter- } \\
\text { action }\end{array}$ \\
\hline \multicolumn{5}{|l|}{ Main effects } \\
\hline $10-14$ & 5.72 & $26.71^{\ddagger}$ & $16.15^{\ddagger}$ & $16.36^{+}$ \\
\hline $15-19$ & $3.83 \ddagger$ & 10.45 & 8.04 & 8.05 \\
\hline $20-24$ & $1.86 *$ & $3.43+$ & $3.01^{\dagger}$ & 2.99 \\
\hline $25-29$ & - & - & - & - \\
\hline not married & 214.80 & 40.73 & $107.88^{+}$ & 109.57 \\
\hline married & - & - & - & - \\
\hline $\begin{array}{l}\text { households with no } \\
\text { non-kin }\end{array}$ & $6.17 \neq$ & $7.68+$ & $6.84^{t}$ & 6.70 \\
\hline households with non-kin & & & & \\
\hline $\begin{array}{l}\text { foreign born } \\
\text { native born }\end{array}$ & $0.54^{\dagger}$ & $0.39+$ & 0.43 & $0.25^{+}$ \\
\hline $\begin{array}{l}\text { no earnings reported } \\
\text { earnings reported }\end{array}$ & $9.53^{\dagger}$ & $4.95^{\dagger}$ & $5.81^{\ddagger}$ & 5.92 \\
\hline on farm & 1.74 & 1.14 & $1.31 *$ & $1.31^{\dagger}$ \\
\hline off farm & - & - & - & - \\
\hline visible/Aboriginal & $0.50 *$ & $2.13^{\dagger}$ & 1.34 & 1.19 \\
\hline Eastern European & 0.68 & $2.85^{\dagger}$ & $1.79 *$ & 0.35 \\
\hline Northern European & 1.15 & 5.34 & $2.70^{+}$ & 1.88 \\
\hline German & 1.05 & $2.99+$ & 2.09 & 1.28 \\
\hline French & 0.54 & $2.25^{\dagger}$ & 1.35 & 0.97 \\
\hline Irish & 0.82 & $1.50 *$ & 1.24 & 1.04 \\
\hline Scots & 0.71 & $1.92^{\ddagger}$ & $1.39 *$ & 1.04 \\
\hline English & - & - & - & - \\
\hline female & & & $1.55^{+}$ & 1.52 \\
\hline male & & & - & - \\
\hline \multicolumn{5}{|l|}{ Interaction term } \\
\hline visible*foreign & & & & 0.56 \\
\hline East Euro*foreign & & & & 7.52 \\
\hline Northern Euro*foreign & & & & 2.15 \\
\hline German*foreign & & & & $3.01^{+}$ \\
\hline French*foreign & & & & $3.10 *$ \\
\hline Irish*foreign & & & & 1.50 \\
\hline Scots*foreign & & & & 2.78 \\
\hline
\end{tabular}


Parents, Children, and Family Formation in the Early Prairie West 605

TABLE 4 (continued)

\begin{tabular}{|c|c|c|c|c|}
\hline Characteristics & Model I & Model 2 & $\begin{array}{l}\text { Model } 3 \\
\text { Women } \\
\text { \& Men }\end{array}$ & $\begin{array}{c}\text { Model } 4 \\
\text { Model } 3 \\
\text { \& Inter- } \\
\text { action }\end{array}$ \\
\hline Intercept (raw coefficient) & -7.84 & -7.52 & -8.22 & -8.05 \\
\hline log likelihood & 562.91 & 770.93 & $1,413.52$ & $1,390.35$ \\
\hline pseudo R square & 0.57 & 0.49 & 0.52 & 0.52 \\
\hline $\mathrm{N}$ & 2,455 & 2,951 & 5,406 & 5,406 \\
\hline
\end{tabular}

Source: PUMS, Census of Canada I9oI

category, whose estimate is omitted from the reported results, is specified for each explanatory variable. In the case of ethnicity, English is the reference category to which all the other estimates are contrasted; for instance, an odds ratio of 2.85 next to the East European category means that a young person of East European origin was 2.85 times more likely than someone with English ancestry to be at home. Since the estimates are generated from a sample population, some test of their statistical significance is necessary to know whether the results could not simply be generated at random. The superscript symbols denote levels of statistical significance, or robustness, of each estimate.

After controlling for the differences between individuals within these groups - in age, birthplace, marital status, earnings, farm status, presence of non-kin - we see a slightly higher tendency for members of recent immigrant groups to remain at home. But it is evident that the contrasts are highly gendered and limited in some way to the foreignborn generation. As we saw earlier, higher proportions of English youth were working as servants, and with the English set as the reference group in the regressions, it is not surprising that significant ethnic contrasts emerge. However, when young women and men are pooled separately, in the first two models in table 4 , we see that the effect of ethnicity all but disappears for young women. Marriage was the largest factor regulating women's transitions to independence and, in a frontier context, with ample opportunity to form new households, the timing of marriage occurred with remarkable uniformity in the sample population. Unmarried women were 2I4 times more likely than married women to 


\section{The Canadian Historical Review}

be still be at home, whereas unmarried men were only 40 times more likely to be at home than married men. Thus, ethnic variation was almost entirely limited to the differences found in the population of young men, at least in terms of individual transitions to independence.

It is unclear, though, how long differences in the male patterns of transition might last. Part of the difficulty, alluded to earlier in the discussion of ethnicity, is that we can identify foreign-born youth but cannot consistently identify the children of immigrants, unless they still resided with their parents. The numbers of foreign-born youth away from home were also elevated in the rural population by the immigration of unattached men to the Prairie West. To genuinely see if parental regimes differed after the eldest children had already left, or at least to control for differences in the level of non-family migrants in each group, an additional partition of the variation was made, beyond the inclusion of birthplace. As the eldest, many foreign born were often the first to leave immigrant homes, and the birthplace variable picks this point up across all four models in table 4 . Nevertheless, if the differences were lasting, the variation should still exist once the contrasts between foreignborn generations are partitioned. But with the introduction of an interaction term in the fourth regression design, the ethnic contrasts declined further in magnitude. With the main effects of ethnicity no longer statistically significant, very little variation in the transitions to independence appears to have existed among the next generations.

If it is possible to argue that patterns of youth transition were not ethnic in nature, how did ethnic difference endure? To start, the contrast between East European and Scandinavian youth offers an important clue. Throughout table 4, Scandinavian youth were shown consistently to remain at home longer, whereas trends among East European youth varied substantially. When young women were pooled separately (model I), East Europeans were among the least likely to be at home. And when an interaction term was added (model 4), a split between native- and foreign-born East European youth emerged. Instead of being in the company of other newcomers, like Scandinavians and Germans, as they appear earlier (model 3), foreign-born East Europeans (as seen in the interaction term) were the most likely to be at home, and the next generation (as seen in the main effects) were among the least likely to be at home. The split makes little sense in terms of the higher degree of sacrifice expected of the children of immigrants or the historic patterns of family formation observed in Europe.

One of the few ways to explain the sudden shift between East European generations - of an older foreign-born experience of youth staying at home and a younger one, far less likely to be with their parents - is 
Parents, Children, and Family Formation in the Early Prairie West 607

seen elsewhere in the data. Tabulations of household composition shown in table 5 reveal an unambiguous orientation among East Europeans towards simple married-couple households. 35 The early marriage encouraged by peasant family formation in Eastern Europe, combined with opportunities for land ownership, seems to have led to the formation of far more independent households in Canada. By contrast, Scandinavians, used to more delay before marriage and greater migration during youth, in economies that were less manipulated by state authorities or post-feudal economic privilege, were in the most complex living arrangements in the region. In this case, the tradition of delayed marriage did not appear to fit well with the relatively small labour markets in the rural West, and Scandinavian youth often returned home, after greater exposure to the outside work, to make their way in the world.

The absence of household complexity among East Europeans is striking and confirms the revisionism of recent case studies. In contexts where peasant proprietorship had been tightly regulated, as in the Baltic states, independent proprietorship was often not achieved without a high degree of household complexity. ${ }^{36}$ But in other areas of Eastern Europe, where property relations were less defined or where common property was not yet subdivided, such as pastoral regions of the Balkans, simple family units were typical of agricultural populations. 37 In western Canada, the literature on Ukrainian settlement lends the impression that farm families were simple households, formed by couples wed at young ages, with marriages occasionally arranged by parents. ${ }^{38}$ The absence of extended family households has been explained as an outcome of federal land policy which, because it required settlers to live on their homestead claims, prevented the formation of traditional villages. 39 This explanation

35 The family types were based on the composition of the first kin group in a household, as developed by the Canadian Families Project. The thirty-six categories in the project's 'famtype' variable were reduced to eight, and the original classification modified slightly by recoding ten households identified as 'multiples' to 'extended,' based on the presence of extended kin such as grandchildren or grandparents. The eight-way presentation of family types is modelled the analysis of American family structure, by Ruggles, 'The Transformation of American Family Structure,' table I.

36 Wetherell and Plakans, 'Borders, Ethnicity, and Demographic Patterns'

37 Gruber and Pichler,'Household Structures'

38 Swyripa, Wedded to the Cause; Orest Martynowich, The Ukrainians in Canada: The Formative Period, 1891-1924 (Edmonton: Canadian Institute of Ukrainian Studies Press I991); Lehr, 'Crown, Corporation, and Church'; and Darlington, 'The Ukrainian Impress on the Canadian West'

39 John C. Lehr and Jeffrey Picknicki Morski, 'Global Patterns and Family Matters: Life History and the Ukrainian Pioneer Diaspora,' Journal of Historical Geography 25, 3 (I999): 349-66 
TABLE 5

Distribution of Individuals by Household Composition and Ethnicity, Farm Population, Prairie West, I90I

\begin{tabular}{|c|c|c|c|c|c|c|c|c|c|}
\hline Household Composition & $\begin{array}{l}\text { Visible } \\
\text { Minority }\end{array}$ & $\begin{array}{c}\text { East } \\
\text { European }\end{array}$ & $\begin{array}{c}\text { North } \\
\text { European }\end{array}$ & German & French & Irish & Scots & English & Total \\
\hline & \multicolumn{9}{|c|}{ per cent } \\
\hline Primary individuals & 1.7 & 0.8 & 1.0 & 1.0 & 2.2 & 3.4 & 3.0 & 3.6 & 2.5 \\
\hline Single parents & 4.0 & 0.8 & 4.1 & 1.1 & 1.2 & 1.9 & 3.7 & 3.3 & 2.4 \\
\hline \multicolumn{10}{|l|}{ Lone head households with } \\
\hline non-kin & 0.0 & 0.8 & 1.3 & 0.6 & 1.6 & 2.4 & 2.5 & 3.6 & 2.1 \\
\hline Childless couples & 1.2 & 3.5 & 4.6 & 2.9 & 1.7 & 2.4 & 1.6 & 2.9 & 2.5 \\
\hline Couples with children & 54.2 & 84.5 & 48.5 & 69.6 & 69.5 & 54.7 & 48.7 & 51.1 & 58.6 \\
\hline \multicolumn{10}{|l|}{ Married couple households } \\
\hline with non-kin & 11.2 & 3.4 & 19.6 & 14.5 & 12.2 & 23.9 & 20.8 & 20.3 & 17.7 \\
\hline Extended & 16.7 & 6.0 & 16.8 & 7.1 & 8.6 & 7.0 & 13.5 & 9.7 & 9.6 \\
\hline \multirow[t]{3}{*}{ Extended with non-kin } & 11.0 & 0.3 & 4.1 & 3.2 & 3.0 & 4.3 & 6.2 & 5.4 & 4.5 \\
\hline & \multicolumn{9}{|c|}{$\mathrm{N}$} \\
\hline & 347 & 916 & 388 & 1,902 & 827 & 1,935 & 2,133 & 2,611 & 11,059 \\
\hline
\end{tabular}

Source: PUMS, Census of Canada I90I 
Parents, Children, and Family Formation in the Early Prairie West $6 \circ 9$

has merit because of the physical space required by much larger farms in western Canada, but the response of Scandinavians to a similar institutional setting suggests that household complexity was just as likely to be the outcome of the land system's design.

In the end, the strongest evidence in the census of enduring ethnic difference are these patterns of household formation and the degree of interest shown in re-creating an agricultural way of life by newcomers. East European parents may have encouraged the formation of young households, for instance, but also did little during the initial stages of settlement to expose children to skills that might take them away from the farm economy. Scholars have debated at great length why these conditions prevailed, some citing slow improvement overseas as an optimistic trend, and others seeing Malthusian flight as the result of peasant resistance to imperial reforms. $4^{\circ}$ However, because minorities were often denied an education in their own language in Eastern Europe, imperial states like Austria-Hungary, even after making education compulsory, could report only slow progress in boosting school attendance by the end of the nineteenth century. ${ }^{\mathrm{T}}$

Despite the best efforts of progressive settlers in Canada, this pattern was largely repeated in the early West. Because it took time for municipalities, which shouldered most of the cost, to generate tax revenues and build school facilities, delays were routine under frontier conditions. Nevertheless, school exercises could proceed even where the ubiquitous one-room school house had not been built. ${ }^{42}$ Scholars like Orest Martynowich write critically of farmers who resisted the cost of education. The material ambitions of these sceptics seem clear enough, as the words of one farmer from east-central Alberta attest: 'We came here to plough not to build schools.' 43 These attitudes towards education became the subject of concerned debate in the pages of Ukrainian newspapers in western Canada, and the editors of Svoboda, Kanadyiskyi farmer, and

40 See Stella Hyrniuk's, 'Peasant Agriculture in East Galicia in the Late Nineteenth Century,' Slavonic and East European Review 63, 2 (1985): 228-43.

4I An Austro-Hungarian report, cited by Martynowich, found that only 7I percent of Galician children attended school nearly three decades after education was made compulsory in I873. A recent study of Polish Galicia concludes that conditions changed little by the First World War. See Martynowich, Ukrainians in Canada, Io, and Jan Molenda, 'War, Children and Youth: The Impact of the First World War upon Changes in the Position of Children in the Peasant Family and Community,' Acta Poloniae Historica 79 (1999): I6I-84.

42 Loewen, Family, Church and Market; Sutherland, Growing Up; Sylvester The Limits of Rural Capitalism

43 Martynowich, Ukrainians in Canada, 343 


\section{6io The Canadian Historical Review}

Ukrainskyi holos admonished readers who wrote in to oppose the formation of school districts as a tax grab, an attack on new freedoms, or a plot by 'radicals.' Pro-education parents were alarmed that, according to their own estimates, only one-third of Alberta's Ukrainian population had formed school districts as late as I9II. 44

However imperfect, the impression given by activists was not very far from the picture painted years earlier in the census. Parents were asked in I90I, for instance, to report on the number of months children had attended school in the previous year. The estimates presented in table 6 suggest that rural farm children were asked by their parents to miss just over one month more of the school year than rural children living off the farm. The foreign born could expect to stay home for a further two months than the native born. A child of East European origin missed as much as four months of school, compared with one month by Englishorigin children in the Prairie West. However, unlike the analysis presented in table 4 , the effects of ethnicity were not limited to the foreignborn generation. An interaction term did not budge the estimates for ethnicity, suggesting that these trends were cultural influences that had lasting importance.

Parents, who quite logically saw their best chances of material improvement in farm ownership and in maintaining tightly woven family networks, were not yet prepared to see the benefits promised from investments in education. They came from a world that had been defined for centuries by unbending social hierarchy, where education served the purposes of others. It was therefore rational to avoid an expense long seen as unnecessary to making a living, particularly given the immediate bounty of acquiring land in lots sixteen to twenty times larger than traditional peasant holdings. As one farmer put it in I9I4: 'If we feed freeloaders [teachers] to play with our children, we will never make our fortune here.' 45 In time, as the farm economy grew crowded and public lands fell into shorter supply, the attitudes of succeeding generations grew less sceptical. Through unique historical circumstances, however, former peasant peoples quickly arranged themselves as 'modern' families and shortened the social distance between themselves and their adopted homeland. An adjustment so brief could only have its beginnings in the Old World and reflected singular ambitions to live a simple and materially rewarding life in the New.

44 Ibid. 
Parents, Children, and Family Formation in the Early Prairie West 6II

TABLE 6

Estimated Months in School among School-Aged (6-I4) Children by Sex, Ethnicity, Location, Nativity, and Age, Canadian Prairies, I90 I

\begin{tabular}{|c|c|c|}
\hline & Model I & Model 2 \\
\hline \multicolumn{3}{|l|}{ Main effects } \\
\hline intercept & 5.4 & $5.3+$ \\
\hline female & 0.2 & 0.2 \\
\hline male & - & - \\
\hline visible/Aboriginal & $-2.5^{+}$ & $-2.5^{\ddagger}$ \\
\hline Eastern European & -4.2 & $-4.2^{\ddagger}$ \\
\hline Northern European & $-2.1^{\dagger}$ & $-2.0^{\ddagger}$ \\
\hline German & $-1.4^{\dagger}$ & $-1.3^{\dagger}$ \\
\hline French & -0.4 & -0.6 \\
\hline Irish & 0.2 & 0.4 \\
\hline Scots & 0.2 & 0.2 \\
\hline English & - & - \\
\hline non-farm & 1.3 & 1.3 \\
\hline farm & - & - \\
\hline foreign born & $-2.0^{+}$ & -1.8 \\
\hline native born & - & - \\
\hline age $5-9$ & $0.8^{+}$ & 0.8 \\
\hline age $10-14$ & $2.1^{\ddagger}$ & $2.1^{*}$ \\
\hline age $15-19$ & - & - \\
\hline \multicolumn{3}{|l|}{ Interaction } \\
\hline visible*foreign & & 5.7 \\
\hline East Euro*foreign & & -0.2 \\
\hline Northern Euro*foreign & & -0.4 \\
\hline German*foreign & & -0.2 \\
\hline French*foreign & & 1.2 \\
\hline Irish*foreign & & $-1.2^{*}$ \\
\hline Scots*foreign & & -0.2 \\
\hline R squared & 0.248 & 0.256 \\
\hline $\mathrm{N}$ & 2,826 & 2,826 \\
\hline
\end{tabular}

Source: PUMS, Census of Canada I90I

$$
* * *
$$




\section{I2 The Canadian Historical Review}

Viewed at the level of individuals and farm households, beneath shared outward manifestations, the practices of immigrant farm families differed far less from native-born farm families than Canada's early social science theorists imagined. During the early agricultural settlement of the Prairie West, the youthful composition of immigrant farm populations did not support an excessive reliance on family labour nor, in the near term, did age composition significantly delay the formation of independent households. Whether the degree of difference became more pronounced over time is an open question. But at the beginning of the twentieth century only Scandinavian youth demonstrated consistent signs of delay in their transitions to independence, whether in terms of higher levels of 'binding out' or of return to parental households that were more complex and intergenerational. At the individual level, the effect of ethnic difference appears to have been isolated largely to the transitions experienced by foreign-born generations of ethnic farm youth.

It is therefore difficult to argue that the paths followed by immigrant children diverged dramatically from those followed by native-born chil-

dren. Immigrant farm parents were not able to exact a higher degree of selflessness from their offspring, measured in this way, certainly not enough to underwrite the persistence of continental mindset in the western landscape. By and large, European youth moved just as quickly to form their own households as the native born, and immigrant parents were no more likely to create complex households and prolonged coresidence with adult children than native-born parents. Instead, 'higher expectations' to stay and to labour were largely visible among the eldest of the most recent arrivals, the foreign-born generation of ethnic farm youth. Immigrant parents had to rely on their eldest to a greater degree that their neighbours did. But in a short time, the special burdens imposed on the eldest came to resemble those shared by other rural children, who also experienced the growing distance of life in the countryside from the literate, civic-minded, and urbanizing worlds that social reformers hoped to build for children. By merely re-creating and adapting familiar forms of family and generational succession, however, immigrant farm families were not inventing enduring ethnic difference. 